\title{
ACADEMIC HARDINESS, SKILLS, AND PSYCHOLOGICAL WELL-BEING ON NEW STUDENT
}

\author{
Ria Wardani \\ Faculty of Psychology, Maranatha Christian University \\ Jl. Prof. Drg. Suria Sumantri No. 65 Bandung \\ riawardani_p@yahoo.co.id
}

\begin{abstract}
This study aims to determine the academic hardiness of new students and use a model that integrates transformational coping, social support, and psychological well-being. As individuals undergoing a period of educational transition, new students need to adapt to the requirements and academic tasks that are different from schooling and insist on them to demonstrate their strong persistence personalities and develop their psychological well-being. This study uses a non-experimental cross-sectional research design. A total of 237 participants filled out the academic hardiness, skills, and psychological well-being questionnaire, and the data were analyzed with SEM version 8.80. The test results show that academic hardiness plays a direct role in developing participant's psychological well-being. Even though academic hardiness plays a role in developing transformational coping and social support skills, both skills do not play a role in fostering psychological wellbeing. These results indicate that commitment - control - and challenges that reveal participants' ability to adapt to the new academic demands can improve their individual ability to demonstrate their fully functioning self or fully functioning person in completing academic demands and tolerating pressures. However, a similar role does not find transformational coping skills and social support skills as the product of academic hardiness. The skill level does not determine the development of the participant's psychological well-being.
\end{abstract}

Keywords: transition period; academic hardiness; transformational coping skill; social support skill; psychological well-being

\begin{abstract}
Abstrak
Penelitian ini bermaksud memahami hardiness akademik pada mahasiswa baru dalam bentuk model yang mengintegrasikannya dengan transformational coping, dukungan sosial, dan kesejahteraan psikologis. Sebagai individu yang tengah mengalami masa transisi pendidikan, mahasiswa baru perlu beradaptasi dengan tuntutan dan tugas-tugas akademik yang berbeda sehingga mengharuskannya menampilkan kepribadian yang penuh dengan daya tahan. Kemampuan beradaptasi di lingkungan pendidikan baru, membuka peluang terbangunnya kesejahteraan psikologis. Menggunakan desain penelitian cross-sectional non eskprerimental dengan ukuran responden 237, penelitian ini membuktikan bahwa hardiness akademik secara langsung mendukung terbangunnya transformational coping, dukungan sosial, dan kesejahteraan psikologis pada mahasiswa baru. Sekalipun transformational coping dan dukungan sosial berhubungan signifikan, secara langsung keduanya tidak menentukan terbangunnya kesejahteraan psikologis. Temuan ini menunjukkan, hardiness akademik dalam konteks kesejahteraan psikologis dapat diteliti tersendiri tanpa melibatkan luaran langsungnya, yaitu transformational coping dan dukungan sosial.
\end{abstract}

Keywords: academic hardiness; transformational coping; kesejahteraan psikologis; dukungan sosial

\section{INTRODUCTION}

The transition from one level to the next level of education reflects the top-dog phenomenon (Santrock, 2017). The transition began with the status as the smallest, youngest, and less power student and then turned to become the oldest, biggest, and most powerful student in the highest level of school education. This phenomenon will be experienced by high school students when they move to a higher level of education to the university. They will experience the transition from the largest, oldest, and powerful groups (when in high school) to first-year students, youngest, and less power 
(when becoming first-year students). Besides, entering higher education brings adolescents to a larger, more impersonal, and broader structure in interacting with peer groups from different geographical and ethnic areas, as well as focus and attention alteration. The new student will be more focused on achievement, performance, and evaluation.

The transitional phenomenon mentioned above has both positive and negative aspects. The positive aspect is that individuals feel they have grown bigger, have many fields of study options according to their talents and interests, are freer to gather with peers, and participate in many activities with minimal parental control. Meanwhile, the negative aspect is that a transitional period implies a fundamental transition of an individual's life, potentially causing a stressful condition (Santrock, 2017). The pressure in the transition period is mainly caused by the striking differences in the models and study demands between high school and tertiary education and the social environment at the overall tertiary level. Heikkilä, Lonka, and Niemivirta (2012) state that academic stress is often found in students. The reason for the statement becomes a very popular topic and interested to be examined. Furthermore, Spiridon and Evangelia's (2015) research shows that students are exposed to academic stress sources that affect their physical and psychological health.

Broadly, individual personality will respond to the perception and internalization of stress. More than two decades ago, the construct of hardiness was considered an essential personality variable that can potentially reduce the impact of stress on health (Maddi, Harvey, Khoshaba, Fazel, \& Resurreccion 2009; Sheard, 2009). The underlying assumption is that a strong personality is not easily threatened or disturbed by various pressures that often approach human life, including students in higher education. A hardy student will react to new circumstances and environments with significant interest and goals, reviewing academic requirements as challenges that can be overcome with hard work and high efforts to successfully adjust to the new academic environment (Johnsen, EId, Palessen, Bartone, \& Nissestad., 2009). Thus hardy students interpret academic pressure as an opportunity to grow and develop the self instead of jeopardizes. Keen students can even feel comfortable and thrive under the stresses confronted in a demanding environment.

According to Maddi, Harvey, Khoshaba, Fazel, and Resurreccion (2009), in order to be resilient in stressful situations, individuals need to maintain three critical attitudes: commitment, control, and challenge (3C). Individuals with commitment (as opposed to seclusion) mean individuals with a strong aspiration involve themselves in various activities. Individuals with high commitment will choose to involve themselves (not avoid), perceive the situation being experienced as something exciting, meaningful, and valuable (Maddi et al., 2009). Individuals with control (as opposed to powerlessness) reflect individuals wanting to involve themselves continually and do not depend on the benefit of the results, but they focus on dealing with difficulties and severe pressure (Maddi et al., 2009). A hardy person will control every event being experienced as an answer he will live (Maddi et al., 2009). Individuals with challenges (as opposed to security) perceive that life is not easy to predict, so various changes in life will facilitate one's personal development. Therefore, hardy people will recognize that a demanding situation is an opportunity to learn to deal with the situation, and not regard it as a threat. Also, the situation allows one to develop positive feelings about the state of life. People with significant challenges will believe that self-growth through the learning process will lead to the ability to overcome difficulties in life, not the comfort and convenience (Maddi et al., 2009). 
Three attitudes (3C) harmonize and build a mindset of courage. Courage (courage) and motivation are manifested from the three attitudes (3C). Courage leads to skills: transformational coping skills or the ability to change stressful situations into benefits for oneself; and social support skills or the ability to resolve interpersonal conflicts constructively, take action to help and encourage the best solutions for those around them rather than distancing themselves from the social environment when faced with situations of pressure (Maddi et al., 2009). Someone resilient from a stressful situation fosters the three attitudes (3C), and the skills that will be formed will help him continue to improve themselves. This pattern, known as hardiness, is the basis for resilience (Maddi et al., 2009).

In general term, previous researchers used the concept of hardiness as three attitudes (3C) or three personality traits, and seldom consider the skills resulting from the three hardiness attitudes and admit the existence of skills. New students confronted with a variety of tasks and demands for new roles that are different from previous levels of education require transformational coping skills and social support as a form of courage and motivation constructed from the three attitudes (3C). Furthermore, these three attitudes and skills determine the success in overcoming the pressure at the tertiary level of tertiary education. On many occasions, hardiness researchers generally define hardiness as personality characteristics (Kamtsios \& Karagiannopoulou, 2013; Spiridon \& Evangelia, 2015), which develop from an early age and tend to persist over time (Johnsen et al., 2009).

Dogaheh, Khaledian, and Arya (2013) stated, hardiness is a complex personal trait, consisting of three cognitive processes or three integrated attitudes. These attitudes mediate the effects of stress by recognizing changes in circumstances and reducing the stress in life (Hystad, Eid, Laberg, Johnsen, $\&$ Bartone, 2009). Hardiness is mainly related to adjustment and favourable agreement in facing problems and difficulties (Eschleman, Bowling, \& Alarcon, 2010).

Daneshamooz and Alamolhodaei (2012) considered the hardiness and motivation theory to explain and understand how students respond to their academic challenges and expressed their academic Hardiness. Academic Hardiness is an attitude showing students resilience to their academic failures as well as personality traits that can clearly distinguish students avoiding academic challenges and students pursuing academic challenges (Ahmadi, Zainalipour, \& Rahmani, 2013; Creed, Conlon, \& Dhaliwal, 2013).

Kamtsios and Karagiannopoulou (2013), Spiridon and Evangelia (2015) identify components that can explain the diversity of student academic performance. Students perceiving their ability in achieving academic goals through effort and emotional regulation (control) tend to strive and can regulate emotions (control) and want to show personal sacrifice to demonstrate their academic excellence (commitment). Also, he will work hard to produce long term personal growth (challenge), will show oriented learning-based performance rather than performance-based (Kamtsios \& Karagiannopoulou, 2013; Spiridon \& Evangelia, 2015).

New students with high academic hardiness perceive their academic activities as something interesting and exciting (a manifestation of commitment); an activity which becomes his personal choice (the embodiment of control); and as an essential stimulus for learning (an embodiment of the challenge). The perception means that new students with high academic hardiness can overcome problems (not avoiding) so that they live up to academic demands with less experiencing stress; 'Reversing' stressful academic demands into opportunities for growth and development. Despite being in an ambiguous situation, new students with high 
academic hardiness will show a coping pattern in pressing situations and academic assignment and then understanding the meaning of the assignment. (Maddi et al., 2009).

An individual with high hardiness will have a natural safety to deal with stressful elements in life, whereas students with low academic hardiness, occasionally show an increased sign of depression, accompanied by the increased sign of anxiety and psychological distress (Dogaheh et al., 2013). This situation gradually will lead new students to demonstrate a declined performance, so that it eventually widens the likelihood for dropouts.

As an outcome, at the end of the continuity, hardiness predicts the establishment of individuals' well-being (Nayyeri \& Aubi, 2011). The psychological welfare paradigm relates to other constructs, as well as resilience and hardiness (Masten, 2011; Sagone \& Caroli, 2014). The topic of the relationship between psychological wellbeing and resilience is fascinating in the field of positive psychology on human development, which is also compatible with life span perspectives (Sagone \& Caroli, 2014). Furthermore, Skomorovsky and Sudom (2011) found evidence that hardiness is positively correlated to psychological wellbeing and protecting an individual from the possibility of developing anxiety or depression. The research findings from Nayyeri and Aubi (2011) demonstrate that there is a positive relationship between hardiness and hardiness components with psychological well-being.

Sagone and Caroli (2014) state that a resilient individual will typically be able to maintain his physical and psychological health and can recover from stressful events rapidly. Psychological well-being talks about constructs related to positive or optimum functioning (Huta \& Ryan, 2010; Sagone \& Caroli, 2014). The concept of eudaimoniaoriented psychological well-being reflects an approach that focuses on the degree to which the individual's self-fulfillment can realize complete personal functioning.

Hidalgo, Bravo, Martínez, Pretel, Postigo, and Rabadán (2010) construct psychological well-being in multidimensional model consisting of six dimensions: self-acceptance, referring to an essential part of personal wellbeing that emphasizes one's opinion about oneself, and includes positive and negative aspects; positive relations with others, referring to the tenacity, pleasure, and excitement that comes from relationships with others, intimacy and love; autonomy, referring to the ability to be alone (being independent), and live autonomously; environmental mastery, suggesting about the ability to determine or build an appropriate environment for individuals' mental state; purpose in life, referring to the ability to find meaning and direction from experiences, express and set goals in life; personal growth, indicating one's ability to realize their potential and talents, and develop new resources which become the main characteristic of individuals with positive psychological functioning (Huta \& Ryan, 2010).

Different from previous studies about psychological well-being, this study focuses on new students in a stressful state as a result of the learning adaptation process in the tertiary education environment they have just entered. This study examines academic hardiness, involving skills as the result of hardiness in the form of transformational coping and social support. Furthermore, transformational coping and social support are moderator variable, mediating the development of psychological well-being of new students. This study will examine the contribution of the overall variables' role, based on an academic hardiness model with the primary outcome of psychological wellbeing. 


\section{METHOD}

Participants in this study were 237 new active students of the Faculty of Psychology, in the college year of 2015 at X University in Bandung. The research design used a crosssectional non-experimental design, that measured the contribution of each variable, according to the research constructed model.

The researcher constructed all three questionnaires, used in this study, to measure academic hardiness, skills, and psychological well-being. The academic hardiness measures three main components, which refer to the theoretical concepts of Benishek and Lopez (2001). The first component is the commitment, referring to the participant's perception about the benefit of college activity, and belief that the activities have a significant meaning and value in the participant's future. The second component is the control, referring to the perception that participants can control all the tasks that must be completed during the study. The third is the challenge, referring to the perception that various lecture demands and increased material difficulties are natural and normal responsibilities that must be encountered and considered as a meaningful part of participant's self-development. There are nine items in commitment component, for example: "Limited time does not decrease my enthusiasm to complete the task on time." The control component consists of eight statements, for example: "I am fully responsible for the process of completing the task both, individual and in groups." The challenge component consists of ten items, for example: "In my opinion, the assignment in each course is an opportunity to practice skills." The validity of commitment ranges from .362 - .676, control from .394 - .664, and the challenge from .398 - .575. The reliability of the questionnaire is .883 , which categorized as high reliability. A fourth Likert scale is used as respond choices, and it ranges from Strongly Agree to Strongly disagree. Participants were asked to put a cross $(\mathrm{X})$ on the representative answer. A score of four to one is given for positive statements in each item, and vice versa for negative statements.

Questionnaire for measuring skills involves transformational coping skills and social support skills, which are the products of hardiness. Transformational comping skills reflect one's tendency to think and behave effectively in overcoming academic demands so that they can turn them into opportunities for self-development. Social support skills are a person's abilities to perceive support, attention and care from people around him (friends, seniors, parents, lecturers) when they perceive academic pressure and demands, and the ability to understand the quality of constructive relationships with people around him. This measuring instrument considered the theories of Maddi and Khoshaba (2005). The questionnaire consisted of ten items for transformational coping and ten-item for social support. An example of transformational coping items is: "Even if it takes time, I must admit that this ongoing academic assignment teaches me to work harder." An example of social support items is: "I think it is important for group members to discuss the results and their thought before write the report." The results of validity testing for transformational coping ranges .412 to .617 and social support ranges from .460 to .645 , with the reliability of .889 . The estimation reliability of the questionnaire is in the high category. Th questionnaire provides four optional answers, and it ranges from Highly Agree to Disagree. Participants were asked to put a cross (X) under the representative answers. A score of four to one is given for positive statements in each item, and vice versa for negative statements.

Researchers constructed psychological wellbeing measurement tools by referring to the concept of psychological well-being from Ryff (2014). The concept consists of six dimensions. The first dimension is selfacceptance, with an example of the item: "I see the advantages and disadvantages of 
myself positively". The second is positive relations with others, which consists of six statements, with example item: "I like to spend time with friends and build a relationship with friends on campus". The third dimension is autonomy, which consists of three statements; item example is "I tend to follow the opinion of most people". The fourth dimension is environmental mastery, which consists of eleven statements with examples of statements: "Failure leads me to find another best way". The fifth dimension is purpose in life, which consists of eleven statements with examples: "I am trying hard to achieve goals". The sixth dimension is personal growth, which consists of twelve statements, with example of items: "As a person, I have not changed significantly, compared to me myself in the past." The results of validity and reliability testing for all dimensions are in the range of .345 - .613, with the reliability of .911 . The reliability number is in the high category. Psychological well-being questionnaire provides four answer choices: Strongly Agree, Agree, Disagree, and Strongly Disagree. Participants were asked to put a cross (X) under the representative answer. A score of four to one is given for positive statements in each item, and vice versa for negative statements. Data is processed using the Lisrel statistical program with Structural Equation Modeling (SEM) version 8.80 .

\section{RESULTS AND DISCUSSION}

This study examines the academic hardiness on new students by considering the three components of hardiness attitude (commitment, control, and challenge), two skills (transformational coping skills and social support skills), and psychological well-being which contained six dimensions: self-acceptance, positive relations with others, autonomy, environmental mastery, purpose in life, and personal growth. This study applied several steps of data analysis. The data analysis began with testing the adequacy of the academic hardiness model using the SEM criteria.
The results of the data analysis show that based on absolute compatibility measures in the form of chi-square, root mean square error of approximation (RMSEA), root mean square residual (RMR), goodness-of-fit index (GFI), and adjusted goodness-of- fit index (AGFI), the academic hardiness model has fulfilled the absolute match size criteria (Wijanto, 2008) as summarized in Table 1.

Tabel 1.

Goodness of Fit Model of Academic Hardiness

\begin{tabular}{lccl}
\hline $\begin{array}{c}\text { Goodness } \\
\text { of Fit }\end{array}$ & Value & $\begin{array}{c}\text { Criteria } \\
\text { Limit }\end{array}$ & Explanation \\
\hline chi-square & 357.94 & & \\
df & 327 & $p$-value & Model Fit \\
$p$-value & 0.12 & $\geq 0.05$ & \\
RMSEA & 0.02 & $<0.05$ & Model Fit \\
RMR & 0.05 & $<0.05$ & Model Fit \\
GFI & 0.91 & $>0.80$ & Model Fit \\
AGFI & 0.87 & $>0.80$ & Model Fit \\
\hline
\end{tabular}

Following the academic hardiness, the model is confirmed to be fit with the goodness of fit SEM criteria. Later on, the researcher tested the significance to determine the significance of the dimensions, aspects, and items in the variable academic hardiness model, based on the loading factor. Table 2 shows the results, and it is found that there is a statement that is not significant. Item 9 of the social support skills and the autonomy dimension of wellbeing have p-values of $>.05$.

To determine the influence strength of academic hardiness variables and skills variables on psychological well-being variables in this model, researchers processed the data using the Lisrel statistical program with Structural Equation Modeling (SEM) version 8.80. Figure 1 contains the results of the testing variable strength in influencing the academic hardiness model. From these results, it can be seen that there are variables that play a role and do not play a direct role in psychological well-being (in bold print). Besides, based on the loading factor, there is also an insignificant relationship between the 
skills variable, the autonomy dimension, and one social support statement. Figure 1 shows the analysis result of the academic hardiness model, and described in table 3 .

Tabel 2.

Loading Factor Significancy

\begin{tabular}{|c|c|c|c|c|c|}
\hline Variable & $\begin{array}{l}\text { Aspect/indicator/ } \\
\text { Items }\end{array}$ & $\begin{array}{l}\text { Loading } \\
\text { factor }\end{array}$ & t-value & $\mathrm{p}$-value & Explanation \\
\hline Academic & Commitment & .80 & 14.58 & $<.001$ & Significant \\
\hline \multirow[t]{2}{*}{ Hardiness } & Control & .80 & 14.50 & $<.001$ & Significant \\
\hline & Challenge & .77 & 13.81 & $<.001$ & Significant \\
\hline Ttransformational & Transf Coping 1 & .62 & - & - & Significant \\
\hline \multirow[t]{9}{*}{ Coping Skills } & Transf Coping 2 & .57 & 7.61 & $<.001$ & Significant \\
\hline & Transf Coping 3 & .72 & 9.17 & $<.001$ & Significant \\
\hline & Transf Coping 4 & .71 & 8.19 & $<.001$ & Significant \\
\hline & Transf Coping 5 & .53 & 7.19 & $<.001$ & Significant \\
\hline & Transf Coping 6 & .66 & 8.47 & $<.001$ & Significant \\
\hline & Transf Coping 7 & .58 & 7.75 & $<.001$ & Significant \\
\hline & Transf Coping 8 & .54 & 7.12 & $<.001$ & Significant \\
\hline & Transf Coping 9 & .59 & 7.68 & $<.001$ & Significant \\
\hline & Transf Coping 10 & .52 & 7.03 & $<.001$ & Significant \\
\hline Social Support & Soc support 1 & .50 & - & - & Significant \\
\hline \multirow[t]{9}{*}{ Skills } & Soc Support 2 & .51 & 6.34 & $<.001$ & Significant \\
\hline & Soc Support 3 & .65 & 6.69 & $<.001$ & Significant \\
\hline & Soc Support 4 & .72 & 7.03 & $<.001$ & Significant \\
\hline & Soc support 5 & .62 & 6.60 & $<.001$ & Significant \\
\hline & Soc Support 6 & .68 & 6.95 & $<.001$ & Significant \\
\hline & Soc Support 7 & .67 & 7.46 & $<.001$ & Significant \\
\hline & Soc Support 8 & .60 & 7.33 & $<.001$ & Signifcant \\
\hline & Soc Support 9 & .11 & 1.55 & .12 & Not Sig. \\
\hline & Soc Support 10 & .74 & 7.19 & $<.001$ & Significant \\
\hline \multirow{6}{*}{$\begin{array}{l}\text { Psychological } \\
\text { well-being }\end{array}$} & Self-Acceptance & .79 & - & - & Significant \\
\hline & Positive Relations & .54 & 8.42 & $<.001$ & Significant \\
\hline & Autonomy & .02 & .25 & .80 & Not Sig. \\
\hline & Environmental mastery & .83 & 13.81 & $<.001$ & Significant \\
\hline & Purpose in Life & .72 & 11.70 & $<.001$ & Significant \\
\hline & Personal Growth & .75 & 12.36 & $<.001$ & Significant \\
\hline
\end{tabular}

$*$ Note: Significant if $p$-value $\leq 5 \%$ or items loading factor $>.50$

Tabel 3.

Result of Research Model Testing

\begin{tabular}{lcc}
\hline \multicolumn{1}{c}{ Variable } & Power/ correlation & Explanation \\
\hline $\begin{array}{l}\text { Academic hardiness - Transformational coping } \\
\text { skills }\end{array}$ & .88 & Contribute \\
$\begin{array}{l}\text { Academic hardiness - Social support skills } \\
\text { Academic hardiness - Psychological well- }\end{array}$ & .73 & Contribute \\
being & .88 & Contribute \\
Transformational coping - Psychological well- & .01 & No contribution \\
being & & .64 \\
$\begin{array}{l}\text { Social support - Transformational coping } \\
\text { Social support - Psychological well-being }\end{array}$ & .03 & Correlate \\
\hline
\end{tabular}




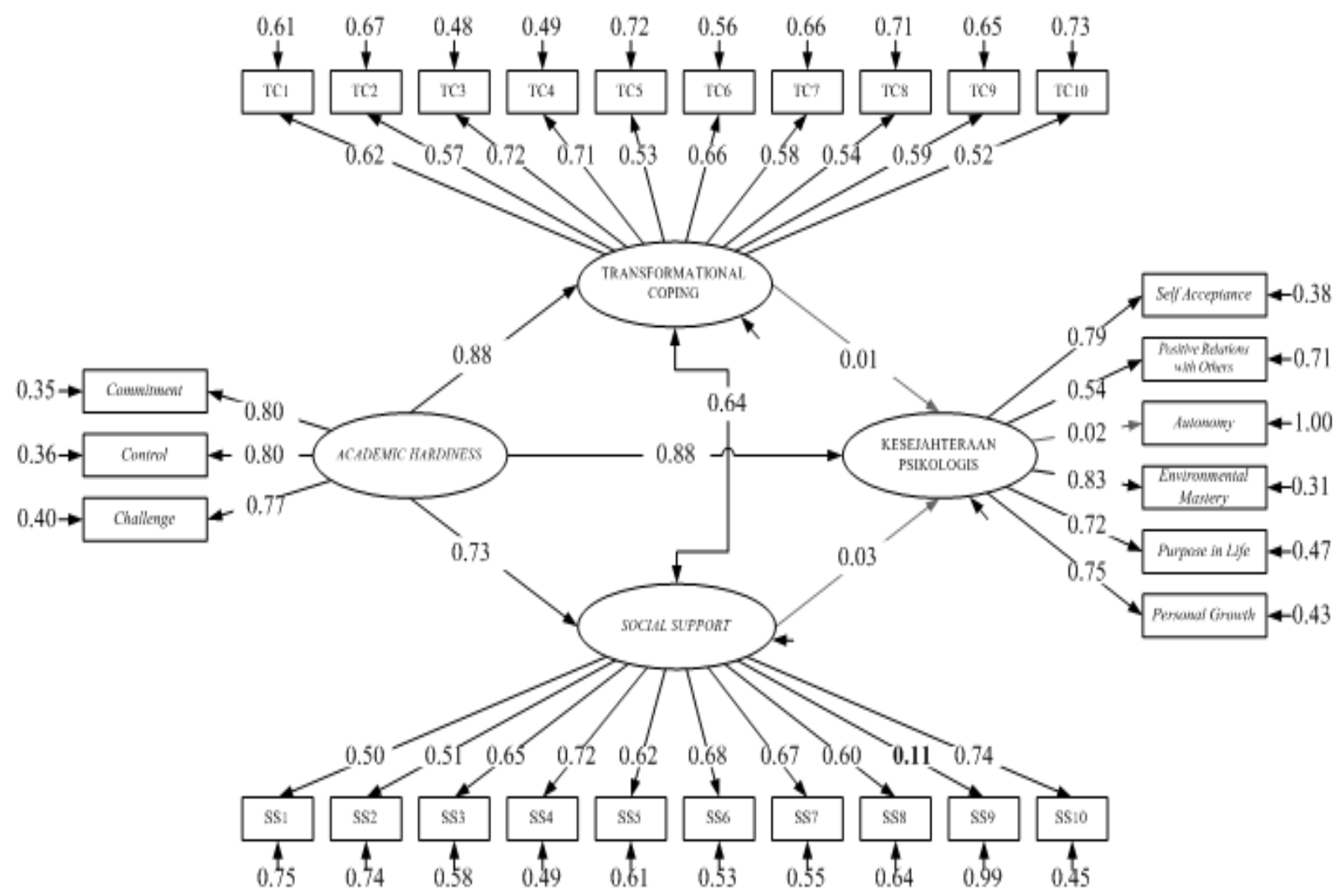

Figure 1. Academic Hardiness Test Results, Skills, and Psychological Well-being

Figure 1 and Table 3 show that participants with hardiness will develop psychological well-being, and it is reflected through five dimensions of well-being, except autonomy. Also, hardy participants will be able to develop transformational coping skills and social support skills. However, these two skills do not play a role in building psychological well-being in the six dimensions of well-being.

Participants with academic hardiness are participants with a persistent personality style, a capacity to organize and survive during a transition period, and pressure as a result of the educational transition (Spiridon \& Evangelia, 2015). The transition from secondary education to tertiary education requires serious participant efforts to achieve adjustment (Santrock, 2017). Various changes must be experienced in the educational transition period, starting from the procedures in enrolling courses, learning methods, class schedules, the variety of assignments, and completion mechanisms, also completely and entirely new and different social environments.

The transition period creates pressure on the participants going through it. However, the new student with academic hardiness will respond differently to the pressure. Hardy individuals will commit firmly and involve themselves in various interpersonal relationships, such as family, friends, and work. Besides, they generally believe that they can control what happens in their lives, and tend to perceive difficult situations as challenges, not threats (Eschleman, Bowling, \& Alarcon, 2010). Someone with personality hardiness will not easily be threatened or disturbed by stressful conditions. As a new student, participants are expected to react to the new conditions with complete interest and sincere goals, perceive academic requirements as challenges that can be overcome by significant efforts, and successfully adapt to the new academic 
environment (Hystad, Eid, Laberg, Johnsen, \& Bartone, 2009). Thus, new students will perceive academic stress as something less dangerous, and they will turn academic pressure into opportunities to grow and develop (Hystad et al., 2009).

The three attitudes in hardy personalities (commitment, control, and challenge) provide courage and motivation to turn stressful events that potentially cause problems in life into an opportunity to grow (Maddi et al., 2009). Furthermore, courage and motivation built from the three hardiness attitudes impact the establishment of transformational coping skills and social support skills.

The results of this study indicate that academic hardiness plays a role in building transformational coping skills and social support skills, which at the same time, confirm the theory of Maddi and Khoshaba (2005). Academically hardy attitudes build a person's coping skills and make him able to develop thoughts and behave effectively in overcoming academic demands. This attitude reflects the participant's ability to alter the pressure situation into an opportunity to develop himself. Likewise, hardy attitudes displayed by participants can help individuals to develop social support perceptions that people around them (friends, seniors, lecturers, parents) give them attention and care in facing various academic demands. Besides, individuals can perceive relationships as a constructive matter to lead them to be more courageous and motivated to overcome academic demands (Eschleman et al., 2010; Maddi \& Khoshaba, 2005).

Transformational coping skills and social support skills that are developed from courage and motivation confirm the research results of Eschleman et al. (2010) and Maddi and Khoshaba (2005). Their results suggest that hardiness, which is characterized by commitment and deep relationship with family, friends, work, and social activities, enables hardy people to develop productive social relationships that can be relied on when someone needs support. Besides, hardy individuals generally have a social appeal, which leads to the easiness of getting social support whenever they need it. Meanwhile, individuals with transformational coping skills and hardiness reflect reasonable efforts in dealing with stress. In this case, they consider a high-stress environment a friendly environment-for example, viewing problems as also experienced by others. As a result, participants with transformational coping skills can promote the impression that they are not alone in facing difficulties and still have a high commitment to struggle to overcome the problems. Transformational coping skills and social support skills can make hardy students manage the pressures in the academic world and turn those stresses into tolerable experiences. The deep understanding of hardy students on the pressure will lead him to make constructive problem-solving efforts by fully utilizing their social relation support.

The analysis of academic hardiness influence on psychological well-being in this study was carried out in two lines (Figure 2), line tested the direct effect, and the line tested the effect through mediating skills variables (transformational coping skills and social support skills). These two lines show different results.

Testing the direct effect of academic hardiness on psychological well-being in this study shows that hardy attitudes academically provide a direct role for the development of participants' psychological well-being. The results mean, hardy academic attitudes can help participants build the ability to overcome emotional and behavioral obstacles while adapting to their academic demands. The results of this study confirm the results study from Sagone and Caroli (2014). They state that the more resilient a person senses, the more able they are to cope with more novelty events in various self-functioning areas, especially in the academic context, to reduce the risk of 
developing maladaptive behavior. Meanwhile, Souri and Hasanirad's research (2011) shows that resilience is a predictor of psychological well-being, and this is in line with the results of the study from Nayyeri and Aubi (2011). The findings state that hardiness is a person's barrier to fighting stressor situations to reduce anxiety and depression. Otherwise, it will increase health, happiness, and positive feelings towards life, and live a prosperous state. Likewise, Teimory and Mashhadi's (2009) research results state that hardiness will predict overall health and well-being conditions and reduce the pressure that comes from the performed tasks. Hardiness is the best predictor of psychological well-being (Skomorovsky \& Sudom, 2011).

The studies examining the role of academic hardiness on psychological well-being indicate different results for the autonomy dimension. The autonomy dimension shows an insignificant role (Table 2). The results of this study confirm the research of Picardi et al., (2012). Picardi et al., (2012) state that there is a positive relationship between resilience (measured through commitment, control, and challenge) and psychological well-being, except in the autonomy dimension. So empirically proven that the results of this study and Picardi et al., (2012), the autonomy dimension shows a different tendency, compared to the other five dimensions. Academic hardiness does not affect autonomy. Autonomy (Ryff, 2014) reflects a person's desire to determine his destiny and tends not to be influenced by people outside himself (independent). Autonomous people can stay away from social pressure to think and act in their way, regulating behavior with personal consideration. Thus, people with autonomy tend to be controlled by internal factors and provide an assessment of situations in the environment based on personal standards. The example of the statement of measuring instrument used is "I am confident with personal opinion even though it must conflict with the agreement of people in general."
The statement of the item's content is not relevant to the participant's efforts as a new student in carrying out the process of adjusting to academic demands in tertiary institutions.

The second path shows the analysis of the role of academic hardiness on psychological well-being mediated by two skills: transformational coping and social support. The results empirically demonstrate that both skills play no role in psychological wellbeing. In other words, the growth of transformational coping skills and social support skills as a result of courage and motivation from the three hardiness attitudes (commitment, control, and challenge) empirically does not mediate the growth of participant's psychological well-being. So it can be said that this empirical finding does not confirm the research of Eschleman et al. (2010), which states that hardy individuals will focus on problem-solving (part of transformational coping skills), show better work and show well-being when faced with pressing situations. This finding also does not confirm Bartone, Hystad, Eid, and Brevik (2012), which state that people with high hardiness tend to count on problem-focused, which is an active coping approach in overcoming pressing conditions. Besides, the empirical findings in this study do not confirm Nayyeri and Auby (2011), stating that coping skills, which are the impact of hardiness, can growth participant's psychological well-being.

This research has successfully proved the effect of academic hardiness on new students on well-being. Academic hardiness variables involve three attitudes: commitment, control, and challenge, moderated by two skills, namely, transformational coping and social support skills. Empirically, academic hardiness determines the participant's psychological well-being. However, academic hardiness mediated by transformational coping skills and social support skills does not have significant strengths that contribute to participants' 
psychological well-being. However, it is expected that through the two skills, participants can adapt optimally in their new environment and build psychological wellbeing (Nayyeri \& Aubi, 2011).

Based on the findings described above, the researcher suggests an additional variable for further research. In order to enrich the research results with the topic of academic hardiness and psychological well-being, further research can involve complete sociodemographic variables, so that the contribution of empirical findings will give a more substantial meaning. Data collection and data analysis on gender, family order, parental education, residence status (living with parents or in student dorm), and place of origin are significant to consider.

\section{CONCLUSION}

New students with academic hardiness in undergoing demands at the tertiary level, will directly predict the development of psychological well-being, especially environmental mastery and self-acceptance. Skills that are the result of academic hardiness do not directly predict psychological well-being, so further research on academic hardiness is better not to include transformational coping skills and social support skills, even though an individual with academic hardiness potentially produces the skills.

\section{ACKNOWLEDGEMENT}

The author would like to thank the Institute of Research and Community Service (LPPM) Maranatha Christian University for the financial support and for allowing the author to complete this research. Besides, the authors are also grateful for sufficient deadlines, which gave more opportunity to complete this research and write the publication. The author also thanked the students for participating in this study and thanks to all colleagues for contributing to this research. The contributions are meaningful, and the writer wants to give appreciation to all sincerity.

\section{REFERENCES}

Ahmadi, A., Zainalipour, H., \& Rahmani, M. (2013). Studying the role of academic hardiness in academic achievement of students of Islamic Azad University, Bandar Abbas Branch. Journal of Life Science and Biomedicine, 3(6), 418423.Retrieved from http://jlsb.scienceline.com/index.php?option=com_conten $\mathrm{t} \&$ view $=$ article $\& \mathrm{id}=26 \&$ Itemid $=31$

Bartone, P., Hystad, S., Eid, J., \& Brevik, J. I. (2012). Psychological Hardiness and Coping Style as Risk/Resilience Factors for Alcohol Abuse. Military Medicine, 177(5), 517-524. doi: 10.7205/MILMED-D-11-00200

Benishek, L.A., \& Lopez, F.G. (2001). Development and Initial Validation of aMeasure of Academic Hardiness. Journal of career assessment, 9 (4), 333352.

Creed, P. A., Conlon, E. G., \& Dhaliwal, K. (2013). Revisiting the Academic Hardiness Scale. Journal of Career Assessment, 21(4), 537554. doi:10.1177/1069072712475285

Daneshamooz, S., \& Alamolhodaei, H. (2012). Cooperative learning and academic hardiness on students' mathematical performance with different levels of mathematics anxiety. Educational Research, 3(3), 270-276. Retrieved from https://www.interesjournals.org/educati onal-research.html

Dogaheh, E. R., Khaledian, M., \& Arya, A. R. M. (2013). The relationship of psychological hardiness with emotional intelligence and workaholism. International Letters of Social and 
Humanistic Sciences, 1(4), 211-217. doi:

10.18052/www.scipress.com/ILSHS.5.1

Eschleman, K. J., Bowling, N. A., \& Alarcon, G. M. (2010). A meta-analytic examination of hardiness. International Journal of Stress Management, 17(4), 277-307. doi:10.1037/a0020476

Heikkilä, A., Lonka, K., Nieminen, J., \& Niemivirta, M. (2012). Relations between teacher students' approaches to learning, cognitive and attributional strategies, well-being, and study success. Higher Education, 64(4), 455471. doi: 10.1007/s10734-012-9504-9

Hidalgo, J. T., Bravo, B. N., Martínez, I. P., Pretel, F. A., Postigo, J. M., \& Rabadán, F. E. (2010). Psychological well-being, assessment tools and related factors. In I.E. Wells (Ed). Psychological WellBeing. New York: Nova Science Publishers.

Huta, V., \& Ryan, R. M. (2009). Pursuing pleasure or virtue: The differential and overlapping well-being benefits of hedonic and eudaimonic motives. Journal of Happiness Studies, 11(6), 735-762. doi:10.1007/s10902-0099171-4

Hystad, S. W., Eid, J., Laberg, J. C., Johnsen, B. H., \& Bartone, P. T. (2009). Academic stress and health: Exploring the moderating role of personality hardiness. Scandinavian Journal of Educational Research, 53(5), 421-429. doi: 10.1080/00313830903180349

Johnsen, B. H., Eid, J., Pallesen, S., Bartone, P. T., \& Nissestad, O. A. (2009). Predicting transformational leadership in Naval Cadets: Effects of personality hardiness and training. Journal of Applied Social Psychology, 39(9), 2213-
2235. doi:10.1111/j.1559-

1816.2009.00522.x

Kamtsios, S., \& Karagiannopoulou, E. (2013). The development of a questionnaire on academic hardiness for late elementary school children. International Journal of Educational Research, 58, 69-78. https://doi.org/10.1016/j.ijer.2012.12.00 1

Maddi, S. R., Harvey, R. H., Khoshaba, D. M., Fazel, M., \& Resurreccion, N. (2009). Hardiness training facilitates performance in college. Journal of Positive Psychology, 4(6), 566-577. https://doi.org/10.1080/1743976090315 7133

Maddi, S. R., \& Khoshaba, D. M. (2005). Resilience at work: How to succed no matter what life throws at you. New York, NY : AMACOM.

Masten, A. S. (2011). Resilience in children threatened by extreme adversity: Frameworks for research, practice, and translational synergy. Development and Psychopathology, 23(2), 493-506. doi: $10.1017 / \mathrm{s} 0954579411000198$

Nayyeri, M., \& Aubi, S. (2011). Prediction well-being on basic components of hardiness. Procedia - Social and Behavioral Sciences, 30, 1571-1575. doi: 10.1016/j.sbspro.2011.10.305

Picardi, A., Bartone, P. T, Querci, R., Bitetti, D., Tarsitani, L., Roselli, V., Maraone, A., Fabi, E., Michele, F. D., Gaviano, I., Flynn, B., Ursano, R., \& Biondi, M. (2012). Development and validation of the Italian version of the 15-item Dispositional Resilience Scale. Rivista Di Psichiatria, 47(3), 231-237. doi: $10.1708 / 1128.12446$

Ryff, C. D. (2014). Psychological well-being revisited: Advances in the science and 
practice of eudaimonia. Psychotherapy and Psychosomatics, 83(1), 1028. doi:10.1159/000353263

Sagone, E., \& Caroli, M. E. D. (2014). Relationships between psychological wellbeing and

resilience in middle and late adolescents. Procedia - Social and Behavioral Sciences, 141, 881-887. doi: 10.1016/j.sbspro.2014.05.154

Santrock, J. W. (2017). Life-span development (13th ed.). Boston: McGraw-Hill.

Sheard, M. (2009). Hardiness commitment, gender, and age differentiate university academic performance. British Journal of Educational Psychology, 79(1), 189204. doi:10.1348/000709908x304406

Skomorovsky, A., \& Sudom, K. A. (2011). Role of hardiness in the psychological well-being of Canadian Forces officer candidates. Military Medicine, 176(1), 7-12. doi:10.7205/milmed-d-10-00325
Souri, H., \& Hasanirad, T. (2011) Relationship between resilience, optimism and psychological well-being in students of medicine. Procedia Social and Behavioral Sciences, 30, 1541-1544. doi: 10.1016/j.sbspro.2011.10.299

Spiridon, K., \& Evangelia, K. (2015). Exploring relationships between academic hardiness, academic stressors and achievement in university undergraduates. Journal of Applied Educational and Policy Research, 1(1), 53-73. doi: 10.7897/2277-4343.04135

Teimory, S., \& Mashhadi, A. (2009). Hardiness and personality characteristics acquired blind students. Journal of Psychological Science, 25, 102-114.

Wijanto, S H. (2008). Structural Equation Modeling. dengan Lisrel 9.8. Konsep dan Tutorial. Yogyakarta: Graha Ilmu. 